
Acta Universitatis Nicolai Copernici • Pedagogika XXX/2014

Nauki Humanistyczno-Społeczne • Zeszyt 422

DOI: http://dx.doi.org/10.12775/AUNC_PED.2014.001

Sebastian Taboł

Uniwersytet Wrocławski

\section{Obraz Sokratesa jako nauczyciela W TEKSTACH STAROŻYTNYCH}

\section{WSTĘP}

okrates jest centralną postacią historii filozofii greckiej. Wielu filo$\checkmark$ zofów wciąż na nowo podejmuje analizę jego myśli. Choć sam nic nie napisał, jego poglądy oraz osobowość znamy z wielu starożytnych pism. Najstarszym źródłem o życiu Sokratesa jest komedia Arystofanesa Chmury. Drugim w porządku chronologicznym są dialogi Platona, które w liczbie 35 zachowały się do naszych czasów. Ze względu na ograniczone rozmiary artykułu, obraz Sokratesa w dialogach Platona zostanie omówiony na podstawie kilku utworów. Trzecim źródłem są dzieła Ksenofonta, który napisał Apologię Sokratesa ${ }^{1}$, Ucztę ${ }^{2}$, Wspomnienia o Sokratesie $e^{3}$ oraz $O$ gospodarowaniu ${ }^{4}$. Natomiast czwarte źródło stanowią teksty Arystotelesa, lecz filozof wspomina go jedynie na marginesie swoich wywodów. Nie miał bowiem możliwości poznać

1 Pojawia się także jako Obrona Sokratesa.

2 Występuje także pod nazwą Biesiada.

3 Funkcjonuje także jako Memorabilia.

4 Tytuł brzmi również O sztuce gospodarowania, Gospodarz, Ekonomik. 
nauczyciela swojego mistrza bezpośrednio ${ }^{5}$. Swieżawski dodaje także relacje zawarte we fragmentach dziejów napisanych przez Antystenesa i Ajschinesa ${ }^{6}$. Do tego zacnego grona należy jeszcze dołączyć Arystypa z Cyreny, Fedona z Elidy, Euklidesa z Megary, Simmiasa i Kebesa z Teb i Diogenesa Laertiosa7. Teksty te nie powstały zaraz po śmierci Sokratesa, więc nie były wyrazem spontanicznego odruchu upamiętnienia mistrza. Świadectwa o Sokratesie wykluczają siebie wzajemnie, jak choćby komedia Chmury Arystofanesa i Obrona Ksenofonta. Dlaczego tak diametralnie różnią się te dwa teksty? I. F. Stone pyta: ,jak wobec różnic między tymi źródłami - ustalić, który z nich jest prawdziwym Sokratesem?"8. Jednakże dotarcie do historycznego Sokratesa nie jest celem niniejszej pracy. Teksty, które zostały poddane analizie, są jedynym źródłem informacji o genialnym filozofie, w których zawarty jest obraz Sokratesa-nauczyciela ${ }^{9}$. Gdyby te teksty nie powstały i nie zachowały się, na pewno nie wiedzielibyśmy, że istniał Sokrates oraz jego filozofia. Sokrates stał się nieśmiertelny dzięki pismom, które krytykował.

Sokrates uważał, że podstawą edukacji było definiowanie pojęć. Jeżeli osoba nie wiedziała, czym jest właściwie obiekt zainteresowań, wówczas nie wiedziała na dany temat nic. Jest to wielki wkład Sokratesa w dzieje myśli filozoficznej. W ten sposób przyczynił się on do rozwoju nie tylko etyki, antropologii filozoficznej, ale również logiki. Rozpoczynanie wywodów naukowych od definiowania świadczy o wielkim uporządkowaniu myślenia Sokratesa, co jest jedną z ważnych cnót, jakie powinien posiadać każdy nauczyciel ${ }^{10}$. Ponadto w analizowanych tekstach nie zawsze wyrażane są sądy o Sokratesie jako nauczycielu. Jednakże jego postawa jako człowieka może stanowić wzór do naśladowania dla wielu współcześnie żyjących nauczycie-

5 G. Reale, Myśl starożytna, tłum. z ang. E. I. Zieliński, wyd. 2, Lublin 2010, s. $110 \mathrm{i} \mathrm{n.}$

6 S. Swieżawski, Dzieje europejskiej filozofii klasycznej, Warszawa-Wrocław 2000, s. 67 i n.

7 J. Gajda-Krynicka, Filozofia przedplatońska, Warszawa 2007, s. 236.

8 I. F. Stone, Sprawa Sokratesa, tłum. z ang. L. Jęczmyk, Poznań 2003, s. 15.

9 I. Krońska, Sokrates, wyd. VI, Warszawa 2001, s. 5-14.

10 I. F. Stone, dz. cyt., s. 84 i n. 
li. Przymioty filozofa predestynują go do roli nauczyciela, choć przed tym etykietowaniem bardzo się bronił.

\section{Sokrates w Chmurach Arystofanesa}

Swoją sztukę Arystofanes wystawił w 423 roku p.n.e. jako piąte dzieło. Głównym bohaterem uczynił Sokratesa, którego winił za wszystko, co złe. Komediopisarz widocznie uznał, że filozof z Aten doskonale nadaje się na temat komedii ze względu na jego liczne dziwactwa, brzydotę oraz sposób bycia, czyli zaczepianie przechodniów i zadawanie im pytań. Sokrates był na przedstawieniu tej komedii i nie obraził się.

Jaki obraz Sokratesa jako nauczyciela zawarty jest w komedii Arystofanesa Chmury. W dziele tym poznajemy filozofa, który uczy swych uczniów teorii, nie mającej nic wspólnego z praktyką. Główny bohater komedii Strepsjades postanowił udać się do szkoły Sokratesa, ponieważ chciał posiąść umiejętności krasomówcze, które pozwolą mu wygrać przed sądem sprawy z dłużnikami, dzięki „zwycięskiej mowie w dobrej czy złej sprawie"11. Początkowo chciał posłać do wspomnianej szkoły swojego syna Fejdippidesa, ale ten odmówił, przy okazji nazywając nauczycieli „myślarni” draniami, chodzącymi bez butów, wariackim towarzystwem oraz szaleńcami. Strepsjades zachęcał syna do podjęcia nauki w tej szkole, bo pracują tam ludzie, którzy nigdy się nie strzygą, nie kąpią i uczą mowy lepszej i gorszej. Jeśli ktoś nauczy się tej gorszej, to wygrywa każdą sprawę w sądzie, nawet tę beznadziejną. Dzięki temu ojciec wyjdzie z długów, w które popadł przez zwyczaje swego syna.

Do podjęcia edukacji przez Strepsjadesa u Sokratesa zmusiła go konieczność. Jako ubogi mieszkaniec podateńskiej wsi ożenił się z majętną kobietą arystokratycznego rodu Megaklesa, która wydawała sporo pieniędzy. Wieśniak miło wspomina czasy, gdy był ubogi, w łachmanach i brudzie. Oprócz matki także syn trwonił pieniądze rodzinne na konie. Niestety szkoła Sokratesa nie nauczyła go nie płacić długów.

11 Arystofanes, Komedie, tłum. z grec. J. Ławińska-Tyszkowska, Wrocław 1991, s. 223. 
Strepsjades określa szkołę jako miejsce uczące „subtelnych wykrętów” o charakterze sofistycznym. Sam te wykręty zastosował w dialogu z wierzycielami, których nauczył się w szkole Sokratesa.

Filozof próbował opornego ucznia zaznajomić z teorią języka oraz z jej wartością artystyczną, aby wywoływać podziw w osobach, które będą słuchały jego kwiecistych sentencji. Sokrates czynił wiele, aby ucznia nie tylko zaznajomić z teorią lingwistyczną, ale także zachęcał go do osobistych starań w tym zakresie. Jak mówi stare przysłowie „Bez pracy nie ma kołaczy”. Żadnych efektów edukacyjnych nie zaobserwowano z racji niskich kompetencji intelektualnych Strepsjadesa. Miał ograniczony potencjał intelektualny. Poza tym z komedii przebija obraz Sokratesa jako nauczyciela chaotycznego. Filozof nie potrafił skoncentrować się na określonym fragmencie rzeczywistości. Badał kosmos, zjawiska ponadziemskie (siedząc w koszu, by zawiesić myśl i rozum), długość skoków pchły, jak brzęczy komar „pyszczkiem czy zadkiem”, analizował myśl teologiczną, obroty księżyca, długość ziemi.

Z lektury Chmur przebija także demoralizująca moc szkoły Sokratesa. Filozof przywołuje chmury, czyli bogów, aby nauczyć „oszustwa i sprytnych wykrętów". Osoby, które wychwalają bogów Sokrates nazywa „nierobami i próżniakami”. Za pewną odpłatą grecki uczony był w stanie nauczyć mowy, która zapewni wygraną w sądzie. Wszystko było tylko kwestią godziwej zapłaty. Jednakże Strepsjades nie nauczył się umiejętności, o które mu chodziło. Opinie o Sokratesie i jego szkole opierał na plotkach. Często nagabywał Sokratesa do wysłuchania jego wywodów o długach, na co filozof nie reagował. W końcu Sokrates nie mógł zdzierżyć braku efektów edukacyjnych ucznia i go po prostu ze szkoły relegował. Strepsjades uświadomił sobie, że jest głupi. Bohater nie pojął nauk swego mistrza, a dodatkowo wykoślawił ich semantykę. Sokrates chciał go nauczyć umiejętności dobrej przemowy, która gwarantowała wygraną nie tylko w sądzie, ale nie obiecywał, że nauczy być oszustem i krętaczem. Przykładał wagę do metrum wypowiedzi, gramatyki słowa oraz sztuki poetyckiej, a nie manipulacji faktami i wykręcania znaczenia argumentów. Strepsjades w końcu zrozumiał, że nie jest w stanie podołać wymaganiom tej szkoły i wysłał do niej swego syna, który szybko nabrał takiej wprawy w argumentowa- 
niu, że wygrywał pojedynki słowne z ojcem. Choć sam Sokrates, gdy go po raz pierwszy zobaczył, nie dawał mu szansy nauczenia się „przekonująco kłamać i unikać sądu". Ponieważ Strepsjades niczego się nie nauczył, z zemsty i frustracji podpalił dom Sokratesa, a podpalanie nazwał „subtelnym dialogiem z belkami" ${ }^{2}$.

W szkole tej wcale nie uczono niemoralności, bo to nie była szkoła sofistów. Takie wrażenie chciał wymóc na czytelniku Arystofanes. Autor komedii uważał, że Sokrates ponosi odpowiedzialność za upadek wychowania. Ponadto przyczynił się do tego, że młodzież odchodziła od tradycyjnych wartości, bogów, a podążała za przyjemnościami, lenistwem, pieniędzmi i sławą. Arystofanes sugeruje także, że Sokrates to gaduła, który zbyt mocno wierzy w moc języka, mogącą rozjaśnić wszystkie mroki niewiedzy. Ponadto Sokrates to człowiek szalony o wyzwolonym umyśle, chodzący boso, znoszący biedę, uczący tylko mówienia i rozumowania, co dla komediopisarza było niedorzeczne. Wmawiał Strepsjadesowi, że Zeus nie istnieje. Filozof nie był w stanie uszlachetnić swoich uczniów oraz odkryć przed nimi tajemnic rzeczywistości.

Być może z powodu napisania i wystawienia tej komedii Arystofanes podał argumenty przeciwko Sokratesowi, na którego od dawna poszukiwano tzw. „haków”, by się go pozbyć lub umieścić w więzieniu. Jednak jest to mało prawdopodobne, ponieważ Sokrates został skazany na śmierć dwadzieścia cztery lata po premierze Chmur, które sławy Arystofanesowi nie przyniosły. Sokrates ukazany jest w tej komedii karykaturalnie. Przypisuje Ateńczykowi sprzyjanie sofistom, odrzucenie tradycyjnych wartości oraz czerpanie korzyści materialnych z uczenia wykrętów i biegłości w argumentacji rzeczy, które zasługują na moralne odrzucenie. Ponadto Sokrates ukazany jest jako zdemoralizowany naukowiec, który pogardza sprawiedliwością i cnotą, przeczy istnieniu Zeusa, przez co demoralizuje młodzież ateńską ${ }^{13}$.

12 R. Flaceliere, Historia literatury greckiej, tłum. z franc, P. Sobczak, Kęty 2004, s. 285-290.

13 B. Russell, Dzieje zachodniej filozofii i jej związki z rzeczywistością polityczno-społeczną od czasów najdawniejszych do dziś, tłum. z ang. T. Baszniak, A. Lipszyc, M. Szczubiałka, Warszawa 2012, s. 116. 
Taki obraz Sokratesa jako człowieka-nauczyciela nie ma nic wspólnego z Sokratesem platońskim ${ }^{14}$.

\section{Dialogi Platona}

Sokrates, jeden z najwybitniejszych filozofów, zastanawiał się, czy cnoty można człowieka nauczyć. Kwestia, której poświęcił swój namysł filozoficzny, miała charakter praktyczny. Po zapoznaniu się z dialogiem Platona Menon, w związku z cnotą Sokrates stawia trzy tezy. Jedna z nich dotyczy nauczania, a brzmi ona: Cnota jest efektem nauczania. Nie będziemy się zajmować innymi tezami, które nie mają związku z analizowanym tematem, ale dotyczą one tego, że cnota pochodzi z natury oraz powstaje za przyczyną boskiego zrządzenia, czyli nie jest efektem nauczania oraz nie pochodzi z natury ${ }^{15}$. Dokonajmy analizy tezy Sokratesa o możliwości nauczenia człowieka cnoty ${ }^{16}$.

Filozof grecki pojmował cnotę w aspekcie intelektualnym, określając ją mianem Fronesis (mądrości). Cnota jest umiejętnością zależną od posiadania przez człowieka owej mądrości. Jednakże filozofa Sokratesa porusza kilka kwestii. Jeśli to prawda, że cnota jest efektem nauczania, więc dlaczego nie istnieją nauczyciele cnoty oraz dlaczego nie ma uczniów, którzy tej cnoty chcieliby się uczyć17. Sokrates podjął wysiłek, aby znaleźć nauczycieli i uczniów ze zrozumieniem pojęcia cnoty, ale jego starania nie przyniosły efektu. To poważnie podważyło postawioną przez niego tezę. Sokrates nie twierdzi jednak, że nie istnieją cnotliwi ludzie. Jednakże społeczeństwo greckie nie wytworzyło systemu, który doskonaliłby moralnie obywateli, czyli nie istnieli nauczyciele cnoty oraz uczniowie. Sokrates w rozmowie z Anytosem (tym, który później oskarżył Sokratesa i w wyniku procesu Sokrates został skazany na śmierć) zastanawiał się, czy w społeczeństwie istnieją mimo wszystko grupy ludzi, których można byłoby traktować jak nauczycieli cnoty. Pierwszą grupą mogliby być sofiści, a drugą tzw.

14 J. Gajda-Krynicka, dz. cyt., s. 238 i n.

${ }^{15}$ R. Legutko, Sokrates. Filozofia męża sprawiedliwego, Poznań 2013, s. 390.

16 Dla Sokratesa cnota była swoistą sprawnością moralną.

17 Platon, Gorgiasz, Menon, tłum. z grec. W. Witwicki, Kęty 2006, s.129. 
"mężowie szlachetni"18. Sofistów odrzucił Anytos od razu, uważając ich za osoby niszczące cnotę, które zresztą nauczają za wysoką opłatą. Postanowił poszukiwać nauczycieli cnoty w przeszłości, w dziejach greckich. Jednakże Sokratesowi chodziło o bezpośredni sposób nauczania cnoty, o wpływ na zachowanie obywatela greckiego przez konkretną i żyjącą postać. Brał pod uwagę Temistoklesa, Arystydesa, Tukidydesa, którzy byli podziwiani i otaczani społecznym szacunkiem, ale Sokrates zapytuje, czy któryś z nich nauczył kogokolwiek cnoty? Nie. Czy przekazali cnotę swoim dzieciom? Nie. Według Sokratesa ci przesławni mężowie, godni tego, aby otaczać ich szacunkiem, swoich synów nauczyli sztuki wojennej, ale nie cnoty. W innym dialogu Protagoras Sokrates podał przykład wielkiej osobowości - Peryklesa, który niestety poniósł porażkę jako ojciec, ponieważ także żadnego ze swych synów nie zaprawił w sztuce bycia cnotliwym, choć sam Perykles był człowiekiem cnotliwym. Sokrates zapytuje jak to możliwe. Także o sobie mówi, że jako ojciec również nie wykazał się skutecznością w nauczaniu cnoty. Wniosek filozofa jest taki, że w ówczesnych Atenach bardzo wiele mówiło się o cnocie, ale efektów nauczania brak. Natomiast Anytos mówił o pośrednim sposobie nauczania cnoty, czyli o uczeniu się cnoty poprzez analizę zachowania mężów, których niestety nie ma w świecie realnym i w związku z tym nie istnieje szansa, aby stali się wzorem zachowania ${ }^{19}$. Czy w związku z tym starożytna Grecja charakteryzuje się niskimi efektami nauczania cnoty i z tego powodu państwo moralnie może chylić się ku upadkowi? W Gorgiasie Sokrates stwierdza przecież, że wielu sławnych mężów greckich należy uznać za pospolitych szkodników. W dialogu tym można zauważyć, jak różne postawy przejawiają Sokrates i Gorgiasz. Sofista jest dumny i pyszałkowaty. Traktuje rozmówców z góry, lekceważy ich, nie docenia wagi pytań, jakie rozmówcy mu stawiają. Jakże inną postawą charakteryzuje się Sokrates: pokorny, aktywnie słuchający, ale bez skrupułów piętnujący wady, które utrudniają innym dotarcie do prawdy, poznanie sedna sprawy. Gorgiasz pysznie twierdzi, że jest w stanie na-

\footnotetext{
18 Tamże, s. 130.

19 R. Legutko, dz. cyt., s. 391 i n.
} 
uczyć każdego sztuki retoryki. Niejeden nauczyciel chciałby pochwalić się taką efektywnością nauczania.

Sokrates w Menonie zastanawia się, jak to jest możliwe, że Temistokles, Arystydes i Tukidydes posiadają rzeczywistą cnotę, lecz nie ma nauczyciela, który by ich tego nauczył oraz oni sami nikogo jej nie nauczyli? Ich cnota niestety nie powstrzymała państwa przed upadkiem, nie jest także kontynuowana i czy w związku z tym bezpowrotnie przepadnie? Można powiedzieć, że jest to fenomen, tajemnica, której Sokrates nie jest w stanie wyjaśnić.

Sokrates nigdy nie mówił o sobie, że jest nauczycielem i że kogoś czegoś nauczył. Zawsze sprzeciwiał się takim opiniom ${ }^{20}$. Nie założył swojej szkoły i nie miał uczniów, choć w Atenach nigdy nie brakowało „uczniów”, którzy za nim podążali i słuchali jego wywodów. Jednak w opinii publicznej był nauczycielem, który przekonywał nie tylko siłą swojego nauczania, ale także swojego przykładu. Filozof ten należy do tych nauczycieli, u których dostrzegało się zgodność deklaracji z postępowaniem, czynami. Sokrates miał misję do spełnienia, którą otrzymał od bogów. Misja ta polegała na badaniu moralnym Ateńczyków i uświadomieniu im braków w rozwoju ku cnocie. Zachęcał obywateli, by zrozumieli, że między cnotą a wiedzą istnieje nierozerwalny związek.

Jako nauczyciel stosował określone metody nauczania. Jedną z nich było nauczanie elenktyczne. Metodą tą Sokrates ukazywał pozorną wiedzę swojego rozmówcy, zbijając jego argumenty. Metoda ta musiała się dla wielu okazać bolesna. Jednakże nie pozostawiał takiej osoby samej sobie, lecz pomagał w dotarciu do prawdziwej wiedzy. W metodzie tej Sokrates udawał prostego człowieka, nie mającego rozeznania w kwestii, o którą pyta, udawał także podziw, co usypiało czujność rozmówcy. Pozwalał osobie wypowiadać zdanie w sprawie, o którą filozof pytał. Słuchał, a następnie zadawał pytania. Podczas tych wypowiedzi wychwytywał niespójność argumentacji osoby, co doprowadzało do tego, że osoba ta często rezygnowała z dalszego artykułowania swojego zdania. Zapewne stosowanie tej metody sprowadziło na Sokratesa oskarżenie o prowadzenie podejrzanych badań,

20 Platon, Obrona Sokratesa, tłum. z grec. W. Witwicki, Kęty 2007, s. 34. 
podczas których ukazywał sposób dokonania, by zdanie słabe stało się mocne ${ }^{21}$. Jeśli rozmówca podczas krzyżowego ognia pytań wycofał się ze swojego stanowiska, stojąc przed Sokratesem jak istota zagubiona, wówczas filozof wspólnymi siłami pomagał mu w znalezieniu odpowiedzi na postawione pytanie. Wykazywał przy tym wiele pokory, ponieważ uważał, że prawda, którą pozna rozmówca, jest wypracowana przez niego samego, siebie przyrównywał jedynie do akuszera. Była to metoda nazywana majeutyką. W metodzie tej chodziło o to, aby rozmówca uświadomił sobie swoją niewiedzę, by zrozumiał, iż wiedza drzemie w nim, ale metodę tę można stosować tylko u wybranych. Są to osoby, w których wiedza naprawdę jest umieszczona i mają pewne określone cechy osobowości, które pozwolą wydobyć z nich nieuświadomioną wiedzę. W Teajtecie Sokrates mówi, że dostaje znak od daimoniona, czy ma kontakt z osobą, która posiada mądrość czy z pospolitym głupcem, zadufanym w sobie ${ }^{22}$.

Sokrates jest tym filozofem, który nie marnuje czasu na zbędne rozmowy i przerywa ją, jeśli jest ona bezpłodna i prowadzi donikąd. Tak jest w dialogu Protagoras. Sokrates jako nauczyciel nie lubi marnować czasu na jałowe dyskusje. W dialogu tym Sokrates zauważa, że jeśli każdy może być autorytetem to nie istnieje zależność ucznia od nauczyciela. Uczenie czegokolwiek nie ma sensu ${ }^{23}$. Nie ma także sensu wymiana myśli, dialogu, spór filozoficzny, poszukiwanie prawdy. Wszelkie spory nic nie dadzą w sensie epistemologicznym i nie sprzyja to poznawaniu świata. Poza tym doświadczenie przebywania w towarzystwie Sokratesa było dla osoby pokornej bardzo owocne. Osoba taka uczyła się definiowania, wzbudzała w sobie refleksję nad życiem, poprawiała swoje błędy w argumentacji. Rozwijała się na oczach Sokratesa, co stanowiło wielki sukces dydaktyczny. Człowiek taki stawał się jednostką rozwiniętą intelektualnie, moralnie, wrażliwszą na problemy państwa, bardziej refleksyjną. Sokrates swoją działalnością nauczycielską podnosił poziom wykształcenia i moralności mieszkańców Aten. Gdyby Sokrates uczył w szkole, zapewne byłby nauczycielem

21 Tamże, s. 35.

22 Tenże, Parmenides, Teajtet, tłum z grec. W. Witwicki, Kęty 2002, s. 89.

23 Tenże, Laches, Protagoras, tłum. z grec. W. Witwicki, Kęty 2002, s. 56-58. 
cnoty, filozofii moralnej, etyki. Ten dobroczynny wpływ Sokratesa na społeczeństwo Aten został ukazany w dialogu Laches, gdzie wypowiada się Nikias, który bardzo chętnie uczył się od Sokratesa ${ }^{24}$. Jednakże w większości przypadków szerokie masy stawiały opór staraniom Sokratesa o ich moralny i intelektualny rozwój. Nie chcieli zmienić swoich nawyków i nie dostrzegali słabych stron w swoim zachowaniu. Sokrates wymagał konkretnych efektów i nigdy nie szedł na skróty czy kompromis. Przekonał się o tym Krition, który zachęcał Sokratesa do ucieczki z więzienia. Sokrates odrzucił tę propozycje, uznając ją za niedorzeczną. Był człowiekiem, który ze spokojem przyjmował niesprawiedliwości tego świata. Wszelkie wysiłki zawrócenia filozofa z raz obranej drogi zawsze kończyły się niepowodzeniem. Sokrates był nauczycielem, którego uczniowie podziwiali i uważali za autorytet. Byli pod nieodpartym urokiem jego osoby, a Sokrates pod urokiem prawdy i cnoty ${ }^{25}$.

Celem podstawowym jego działalności nauczycielskiej była troska o duszę. Nawoływał do życia zgodnego z moralnością i prawdą. Dobro duszy jest rzeczą najważniejszą w życiu człowieka, ponieważ to w niej rodzi się poznanie. Sokrates miał zwyczaj nauczać poprzez pytania i odpowiedzi. Była to dla filozofa główna metoda filozofowania, czyli poszukiwania prawdy o ideach. Poszukiwanie prawdy Sokrates traktował jako cel praktyczny. Dialogi Platona są wyrazem naśladowania metody filozofowania Sokratesa. W ten sposób oddały w sposób wierny metodologię filozofowania. Można także wnioskować, że w taki właśnie sposób Sokrates dochodził do autentycznego spotkania z prawdą o cnocie ${ }^{26}$.

Sokrates, z dialogów Platona, jako nauczyciel otwierał się na drugiego człowieka. Charakteryzowała go wysoka empatia. Jak stwierdza Tomasz Mazur, Sokratesa charakteryzowała postawa otwarcia duchowego i egzystencjalnego na określone doświadczenie. Analizu-

24 Tamże, s. 7.

25 R. Legutko, dz. cyt., s. 404.

26 Problem ten był również podejmowany przez: J. Burnet, Greek Philosophy: Thales to Plato, London, New York 2008 oraz A. E. Taylor, Socrates, reprint, Edynburgh 2007. 
jąc dialogi Platona, dostrzegamy, że jego życie było podporządkowane zasadzie prawdy. Egzystencja Sokratesa polegała na poznaniu praw$\mathrm{dy}^{27}$. Ponadto jego postawa wykazała, że nie można być nauczycielem i człowiekiem obłudnym. Oczywiście bycia nauczycielem nie należy rozumieć współcześnie. Dla Sokratesa, którego naśladowała młodzież, bycie autentycznym było kwestią najważniejszą, nawet jeśli za ową autentyczność należało zapłacić życiem. Nie można być nauczycielem i nie mówić prawdy młodzieży. Największą wartością Sokratesa jako nauczyciela było posiadanie prawdziwej, rzetelnej wiedzy, a czy nie o to właśnie chodzi w pracy dydaktycznej?

\section{Pisma Sokratyczne Ksenofonta}

Spuścizna literacka Ksenofonta jest imponująca. Diogenes Laertios podaje, że na ten dorobek składa się około 40 prac, które zachowały się do naszych czasów. Zdaniem J. Schnaydera pisma Ksenofonta można podzielić na: pisma sokratyczne, historyczne oraz różne ${ }^{28}$. Ksenofont znał Sokratesa około 11 lat. Poznał go prawdopodobnie w 410 r. p.n.e. w 401 r. p.n.e. opuścił Ateny, do których już nigdy nie powrócił, co spowodowało, że jego znajomość z Sokratesem została przerwana i nie mógł być ze swoim mistrzem do końca jego dni. W swoich tekstach nie umieścił własnej osoby, choć ukazuje siebie jako świadka pewnych zdarzeń, co może gwarantować autentyczność jego opisu. Autor sugeruje także, że należał do grona najbliższych uczniów Sokratesa. Według anegdoty zapisanej przez Diogenesa Laertiosa został nim, gdy Sokrates zatarasował mu drogę laską i zapytał go, gdzie można zostać porządnym człowiekiem. Ksenofont nie udzielił odpowiedzi, dlatego Sokrates zaproponował mu, aby udał się z nim w pewne miejsce $^{29}$. Sam otrzymał gruntowne wykształcenie, ale wspomina tylko naukę, którą pobierał u sławnego Ateńczyka. Zatem można oczekiwać,

27 T. Mazur, Kapryśni bogowie Sokratesa. Człowiek i świat wartości $w$ tradycji filozofii zachodniej, Kęty 2008, s. 24 i n.

28 J. Schnayder, Wstęp, w: Ksenofont, Wybór pism, tłum. z grec. J. Schnayder, Wrocław 1996, s. XVII.

29 Tamże, s. X. 
że będzie się o Sokratesie wypowiadał pozytywnie, a nie jak Arystofanes, który skarykaturował filozofa. Jednakże Ksenofont nie był filozofem jak Sokrates, więc miał poważne problemy z ukazaniem go jako naukowca. Był co prawda obserwatorem życia Sokratesa, ale czy zapamiętał i zrozumiał naukę filozofa, można śmiało wątpić. Część opisu życia Sokratesa opierała się na relacjach drugich osób. Jego dzieła opisujące życie mistrza mają charakter wspomnień. Pisane są językiem prostym, pozbawionym elegancji lingwistycznej. A jego relacje $\mathrm{z}$ wydarzeń mają wartość informacyjną o charakterze historycznym ${ }^{30}$.

Z obrazem Sokratesa zapoznajemy się w takich utworach, jak ${ }^{31}$ : Obrona Sokratesa, Wspomnienia o Sokratesie, Uczta oraz O gospodarstwie. Nie są to jedyne prace, które napisał Ksenofont, jednakże do naszych badań wykorzystamy tylko te. Próbując dokonać opisu Sokratesa zawartego w Obronie Sokratesa, dostrzegamy, że zasadniczym elementem tego dzieła jest próba oczyszczenia ateńskiego filozofa z fałszywych oskarżeń. Ten utwór nie jest dialogiem Sokratesa z oskarżycielami, ale dialogiem filozofa z Hermogenesem. Zapewne to od niego Ksenofont czerpał wiedzę o Sokratesie. Dowiadujemy się, jakie argumenty chce przytoczyć na swoją obronę przed sądem. Tekst ten zawiera pięć podstawowych wątków ${ }^{32}$ :

30 Pierwszym, który podważył wartość relacji Ksenofonta o Sokratesie był Schleiermacher. W literaturze angielskiej i amerykańskiej zostało opublikowanych wiele monografii, które podejmują problem relacji Ksenofonta o Sokratesie: A. R. Lacey, Our Knowledge of Socrates, w: The Philosophy of Socrates: A Collection of Critical Essays, red. G. Vlastos, New York 1971; G. Vlastos, Introduction: The Paradox of Socrates, w: The Philosophy of Socrates: A Collection of Critical Essays, red. G. Vlastos, New York 1971; G. Vlastos, The Philosophy of Socrates, New York 1971; G. Vlastos, Socratic Studies, Cambridge 1994; Ch. Kahn, Plato and the Socratic Dialogue: The Philosophical Use of a Literary Form, Cambridge 1998; S. Peterson, Socrates and Philosophy in the Dialogues of Plato, Cambridge 2011; C. Osborne, Socrates in the Platonic Dialogues, „Philosophical Investigations" 2006, nr 1, s. 1-21.

31 Tytuły prac podaję według tłumaczenia dokonanego przez Leona Joachimowicza ze względu na jego współczesną wersję dzieł - zob. Ksenofont, Pisma Sokratyczne, tłum. z grec. L. Joachimowicz, Warszawa 1967.

32 J. Schnayder, Wstęp, w: Ksenofont, dz. cyt., s. XVIII. 
1. Sokrates udowadnia, że nigdy nie popełnił żadnego złego czynu, ale nie spodziewa się wyroku uniewinniającego. Nie oczekuje przedłużenia swojego życia ze względu na starość, która ogranicza jego możliwości intelektualne i fizyczne. Bóg mu podpowiada, aby zakończył życie. Woli umrzeć z wyroku sądu, niż umrzeć ze starości i w chorobie.

2. Sokrates broni się przed zarzutem bezbożności.

3. Wniosek Sokratesa o wymierzenie mu stosowanej kary. Zabronił swoim przyjaciołom i uczniom starać się w sądzie o zmniejszenie wymiaru kary, ponieważ świadczyłoby to o jego bezspornej winie, a Sokrates czuje się niewinny.

4. Przemowa Sokratesa po ogłoszeniu wyroku. Nie przyznaje się do winy i dziwi się, gdzie sąd dopatrzył się jego winy.

5. Zachowanie Sokratesa po zakończeniu rozprawy sądowej. Jest osobą pogodną i pogodzoną z losem. Okazuje także hardość wobec wizji śmierci. Nie ceni swojego życia zbyt wysoko, nie uczyni wszystkiego, aby je zachować.

W Obronie Ksenofont ukazał Sokratesa pogodzonego z życiem, dokonującego rachunku ze swojego życia i działalności. Mistrz nie ma wątpliwości, że postępował sprawiedliwie i moralnie. W jego życiu nie ma żadnego wątku, którego musiałby się wstydzić. Wyrok śmierci przyjmuje z godnością, choć jest on dla niego zaskoczeniem. Nie czuje już chęci do życia, bo głos boży daje mu znak, że czas zakończyć swój ziemski bieg ${ }^{33}$.

Ksenofont w Obronie zawarł wiele szczegółów: zachowanie sędziów podczas rozprawy, barwny opis dnia, w którym rozgrywała się rozprawa sądowa, interpretacja daimonionu-głosu boga. Ksenofont pięknie podsumowuje swoje niewielkich rozmiarów dzieło: „A jeśli ktoś z ludzi dążących do cnoty obcował z jakimś jeszcze pożyteczniejszym nauczycielem niż Sokrates, sądzę, że taki najzupełniej zasłużył na to, aby go nazwać szczęśliwym"34.

33 L. Joachimowicz, Wstęp do przekładu, w: Ksenofont, Pisma Sokratyczne, tłum. z grec. L. Joachimowicz, Warszawa 1967, s. XIII.

34 Ksenofont, Pisma Sokratyczne, tłum. z grec. L. Joachimowicz, Warszawa 1967, s. 13. 
Kolejna praca Ksenofonta, broniąca dobrego imienia Sokratesa, to Wspomnienia o Sokratesie, składające się z 4 ksiąg. W I księdze autor polemizuje z głównymi zarzutami wobec Sokratesa: bezbożnością i demoralizowaniem młodzieży. Jest to główna oś tej pracy. Reszta jest zbiorem luźnych informacji o filozofie, które nie są budowane wokół jakiejś głównej idei. Zdaniem Ksenofonta Sokrates był wzorem człowieka, który wpływał na poziom moralny innych. Był również człowiekiem pogardzającym bogactwem, umiejącym panować nad sobą, podkreślając wartość każdej pracy. IV księga zawiera istotne myśli o metodach wychowania i kształceniu, które były poruszane przez Sokratesa i jego uczniów.

Uczta, składająca się z 9 rozdziałów, to kolejna monografia, w której Ksenofont ukazuje Sokratesa takim, jakim był na co dzień. Uczta odbywa się w domu Kaliasza, który zorganizował spotkanie z okazji zwycięstwa Autolika w zawodach sportowych. Podczas tej uroczystości odbywa się nie tylko spotkanie przyjaciół, którzy raczą się dobrym trunkiem i jadłem, ale podejmowane są dyskusje na wyszukane tematy. Podstawowym tematem jest sztuka, miłość, piękno ciała fizycznego. Sokrates także włącza się do dyskusji, stawiając ważną tezę, że lepsze jest posiadanie pięknej duszy, wnętrza niż pięknego ciała. Sam Ksenofont przyrównał urodę Sokratesa do Sylena. Wychwalał także piękno tańca, które sprzyja zachowaniu zdrowia. Filozof uważa, że człowiek powinien pachnieć szlachectwem duszy, a nie wonnościami ciała. Jednakże Sokrates wyraża pewne opinie o kobietach, które mogą się spotkać z brakiem akceptacji grona feministek. Ateńczyk stwierdza, że kobieta charakteryzuje się brakiem stateczności rozumu, ale powinna być uczona tego wszystkiego, czego uczeni są mężczyźni. Ksenofont wykreował Sokratesa na człowieka, do którego można zwrócić się o każdą radę, bo zna się na wszystkim. Ponadto ma umiejętność przywodzenia człowieka do każdej cnoty. Uważa także, że uroda człowieka ma wielkie znaczenie, bo ludzie urodziwi, piękni mają w życiu większe powodzenie.

Zdaniem Jaegera Ksenofont mówi o oskarżycielu, podczas, gdy Platon o oskarżycielach: Anytosie, Meletosie i Likurze ${ }^{35}$. Ksenofont

35 W. Jaegger, Paideia. Formowanie człowieka greckiego, tłum. z niem. M. Plezia, H. Bednarek, Warszawa 2001, s. 570 i n. 
w swych dziełach stara się bronić Sokratesa przed fałszywymi oskarżeniami. Jednakże jego relacja pochodzi z drugiej ręki. Owe dzieła napisał, gdy był z dala od Aten i sporządził je wiele lat po skazaniu Sokratesa. Ponadto Ksenofont nie był filozofem, dlatego nie mógł za bardzo ukazać postaci mistrza jako człowieka zajmującego się systematycznie myślą naukową. Stara się odtworzyć osobowość mistrza, któremu należy się duża doza szacunku. Ksenofont w swych dziełach stara się przekonać czytelnika, że wspomnienia nie można oddzielić od jego filozofii, która jest marginesem, tłem jego dzieł. Jego dzieła to pochwała mądrości człowieka, który do końca swojego życia był wierny swoim wartościom, za które musiał ponieść śmierć. Jest to w zasadzie literacki, a nie filozoficzny obraz Sokratesa. Ksenofont nie wnikał w myśl filozoficzną, ale analizował osobowość filozofa ${ }^{36}$. Celem dzieł, poświęconych Sokratesowi było oczyszczenie go z zarzutu demoralizowania młodzieży i bezbożności. Platon dodaje także trzeci zarzut: prowadzenie podejrzanych badań naukowych (filozoficznych). Zdaniem Ksenofonta Sokrates był chodzącą cnotą, człowiekiem, który nie doczekał się żadnych uwielbień ani dowartościowania.

\section{ŻYWOTY I POGLĄDY SLYNNYCH FILOZOFÓW Diogenesa LaerTiosa}

W swym dziele Diogenes stwierdza, że Sokrates był nauczycielem retoryki, a także pierwszym filozofem, który zastanawiał się nad jakością życia człowieka, porzucając idee filozofii przyrody. Sokrates, będąc nauczycielem, nie miał łatwego życia, ponieważ w Żywotach dowiadujemy się o tym, jak go traktowano, gdy nauczał: szarpano za włosy, bito po twarzy, drwiono z niego, kopano. Wszystko dlatego, że postanowił podnieść poziom moralny i intelektualny mieszkańców Aten. Chętnie dyskutował z każdym, nikogo nie ignorując, co dobrze o nim świadczy jako nauczycielu. Wszystko po to, aby każdemu pomóc odkryć prawdę. Nie tylko zajmował się nauką, ale był człowiekiem wysportowanym, silnym i zdrowym. Dowiadujemy się, że nie był skon-

36 Tamże, s. 568. 
centrowany tylko na pracy dydaktycznej, ale okazywał się ofiarnym obywatelem kraju. Brał udział w wielu wyprawach wojennych, które mogłyby się dla niego zakończyć śmiercią. Podczas jednej z takich wypraw uratował życie Ksenofonta. Był człowiekiem mężnym, odważnym i cierpliwie znoszącym trudy, a przy okazji nikt nie pamięta, aby się uskarżał na cokolwiek. To dowodzi wielkiej odwagi filozofa. Być może potem jako nauczyciel „uliczny” czerpał ze swego życiowego doświadczenia. Nigdy nie przyłożył ręki do niesprawiedliwego wyroku, był wierny swoim zasadom, co powodowało, że młodzież postrzegała go jako wzór do naśladowania, uznając go za autorytet. Za swoją pracę pedagoga nie pobierał opłaty i cieszył się ze swej umiejętności poprzestawania na posiadaniu niewielu rzeczy. Diogenes podaje przykłady wielu młodych i wysoko urodzonych, którzy wzięli sobie do serca nauki Sokratesa. Do tych osób Diogenes zaliczył: Teajteta, Eutryfrona, Glaukon, Charmenidesa, Ifikratesa i Kalliasa ${ }^{37}$.

\section{ZAKOŃCZENIE}

Analizując obraz Sokratesa zawarty w pismach starożytnych, można z pewną dozą prawdopodobieństwa powiedzieć, że wizerunek filozofa jako nauczyciela był konstruowany pod wpływem tragicznego zdarzenia, jakim było skazanie Sokratesa na śmierć ${ }^{38}$. W ten sposób, jak podaje Jaeger, „rozpoczął się proces krystalizacji płynnego dotąd obrazu Sokratesa w świadomości jego współczesnych"39. Po śmierci filozofa rozpoczął się ruch, który zapoczątkowali uczniowie Sokratesa, mający oczyścić mistrza z zarzutów oraz utrwalenie w świadomości ludzi pamięci o Sokratesie jako człowieku godnym naśladowania. Wśród uczniów Ateńczyka wyrosła tradycja literacka, która poprzez strategię dialogu oraz wspomnienia, opisała żywot Sokratesa. Miało to do-

37 Diogenes Laertios, Żywoty i poglądy słynnych filozofów, tłum. z grec. I. Krońska, Warszawa 2013, s. 91-97.

38 A. E. Taylor, Socrates, reprint, Edynburgh 2007, s. 11; H. H. Benson, Essays on the Philosophy of Socrates, Oxford 1992, s. 36-54; P. Dell, Socrates: Ancient Greek in Search of Truth, Minneapolis 2006, s. 26-29.

39 W. Jaeger, dz. cyt., s. 567. 
wodzić, że nie można oddzielić filozofii od wspomnień o Sokratesie. Dzieła te starały się nie tylko opisać jego dokonania na polu filozofii, ale wniknąć w niezwykłą osobowość filozofa, który odcisnął niezatarte wrażenie na osobach, które miały możliwość przysłuchiwania się jego wywodom i obserwowania jego postępowania. Wielka szkoda, że rozmów, które prowadził Sokrates nikt nigdy nie zapisał. Byłby to wielki intelektualny skarb, jaki pozostawiłby Sokrates kulturze europejskiej, która bez jego pism także się rozwinęła.

W pracy tej nie starano się określić, co jest zgodne z Sokratesem, a co nie. Nie oddzielano „plewy od ziarna”. Dostrzec można pewną regułę, że wszyscy, oprócz Arystofanesa, pozytywnie opisali obraz Sokratesa. Nikt z filozofów starożytnych nie został przez jemu współczesnych tak dobrze i dokładnie opisany jak Sokrates. Nikt nie wkładał swojej duszy w opisanie filozofa z Aten. Powstaje pytanie, czy dzisiaj jesteśmy w stanie odróżnić fikcję od autentycznych przeżyć i wydarzeń? Czy możemy z tych pism poznać prawdziwego Sokratesa? Odpowiedź jest przecząca.

Sokrates jest jedną z najdonioślejszych postaci w historii myśli wychowania europejskiego. Wniósł do historii umysłowej kultury bardzo wiele, chociaż nie napisał żadnej rozprawy naukowej. Stanowi to o wielkim fenomenie tego filozofa. W swej filozofii nie nawiązuje on do żadnego nurtu. Swoją filozofię zawdzięcza własnej ciężkiej i wytrwałej pracy, co stanowi jego dodatkowy atut jako nauczyciela. Nawet w obliczu śmierci Sokrates nie przestawał pracować. W Fedonie dowiadujemy się, że jeszcze tego samego dnia, w którym miał zostać stracony, czytał dzieła Anaksagorasa ${ }^{40}$. Był filozofem, który przyczynił się do zwrotu antropologicznego w myśli filozoficznej, co dla dziejów i rozwoju tej nauki ma ogromne znaczenie. Jako nauczyciel musiał mieć także salę lekcyjną, jaką stanowiło życie ateńskie, ulice, stadion, domy bogatych mecenasów oraz place, na których znajdowali się ludzie, chętni podjąć z nim dialog. Zdaniem Gardinera Ksenofont oraz Platon w swych dziełach umieścili Sokratesa w gimnazjum oraz Akademii ${ }^{41}$. Młodzież z największych i najznamienitszych rodów arystokratycznych Aten

40 Platon, Fedon, tłum. z grec. W. Witwicki, Warszawa 2010, s. 146 i n.

41 E. N. Gardiner, Greek Athletic Sports and Festivals, London 2002, s. 268-301. 
gromadziła się wokół Sokratesa, choć ten nie posiadał szkoły w sensie instytucjonalnym. Nie wynajął żadnego budynku, w którym prowadziłby lekcje. Przyciągał swoją osobowością oraz postępowaniem, które było zgodne z jego ideami.

\section{Summary}

\section{AN IMAGE OF SOCRATES AS A TEACHER IN ANCIENT TEXTS}

The article presents the image of Socrates as a teacher, which runs through the ancient books. The author of no wonder that the image is authentic and which is false. Have been analyzed texts of Aristophanes, Xenophon, Plato and Diogenes Laertius and Aristotle. The account shows a positive image of the philosopher. Only Aristophanes in the Clouds was released it in a satirical way. Although Socrates objected to calling him a teacher, but by educating the youth of Athens and he was and could become a model for today's teachers. Due to the limited volume, which has a product image included in the dialogues of Plato Socrates was only signaled because of the multitude of dialogues, which would be analyzed. 